\section{International Scientific Journal Theoretical \& Applied Science}

p-ISSN: 2308-4944 (print) e-ISSN: 2409-0085 (online)

Year: 2015 Issue: $04 \quad$ Volume: 24

Published: $30.04 .2015 \quad$ http://T-Science.org
Paul M. Taylor

Director of Asian Cultural History Program, Ph.D., Head of Department of Anthropology National Museum of Natural History Smithsonian Institution, Washington, USA

Elnur Latif oglu Hasanov Corresponding member of International Academy of Theoretical and Applied Sciences, Ph.D. postgraduate

SECTION 12. Geology. Anthropology. Archaeology.
Institute of Local-lore of Ganja Branch Azerbaijan National Academy of Sciences,

Ganja, Azerbaijan

1-hasan@hotmail.com

\title{
ABOUT SIGNIFICANCE OF BASIC ART CRAFTSMANSHIP TRADITIONS OF GANJA IN RESEARCH OF ETHNO-HISTORICAL PAST OF THE TURKIC WORLD
}

Abstract: This scientific article deals with the historic-ethnographical importance of development of the main traditional branches of craftsmanship of Ganja. For the first time in this work were systematic investigated the basic skill characteristics of different wares of these handicraft branches and their importance in research of history of the Turkic World.

Key words: handicraft branches, historic-ethnographical investigation, decorative-applied arts, Ganja, Azerbaijan.

Language: English

Citation: Taylor PM, Hasanov EL (2015) ABOUT SIGNIFICANCE OF BASIC ART CRAFTSMANSHIP TRADITIONS OF GANJA IN RESEARCH OF ETHNO-HISTORICAL PAST OF THE TURKIC WORLD. ISJ Theoretical \& Applied Science 04 (24): 15-21.

Soi: http://s-o-i.org/1.1/TAS*04(24)3 Doi: crossef http://dx.doi.org/10.15863/TAS.2015.04.24.3

\section{Introduction}

Ganja city during centuries considered as one of the main urban cultures and located on the ancient caravan routes, so merchants, travelers, scientists and cultural workers from different countries of the world visited Ganja, and first of all, their visiting helped our nation to integrate their spiritual values to all mankind civilizations. During different archeological excavations material-cultural remains have proved that Ganja, which is one of humanity's most ancient settlements, had played an important role in the history of the development of science and culture of our country. This city is situated on the west of Azerbaijan and Ganja is known as a motherland of such famous persons as Nizami Ganjavi, Mahsati Ganjavi and etc. Ganja is one of the oldest cities and has more than 4000 years old as an urban center. Development of some local handicraft branches in this city historically offered necessary facilities for progress of urban culture.

Investigation of ancient craftsmanship traditions of the Turkic World on the basis of local craft wares of Ganja is very important, because:
1. On the basis of different craftsmanship wares of Ganja we can prove the same characteristics between these patterns and other similar wares of Eurasia as the murgob (murgobi) ceramic figures, also various carpet-making, metal-treatment patterns of the Turkic World;

2. Also, for the first time it is possible to prove the importance of local traditional craft wares of Ganja in investigation of historical past development of craftsmanship of such ancient regions as Central Asia, Eastern Europe and etc.

The craftsmanship of carpet-making is one of the important cultural achievements of the Eastern people in Azerbaijan production of carpets appeared during I millennium BC. But carpet-making in the first period of Middle Ages has turned to the independent sphere of craft. In Ganja, that has minimum 4000 years history, production of carpets differed with quickly development. In this ancient city, that is native land of great Azerbaijani poet and thinker Sheikh Nizami Ganjavi, were weaved very uncial, inimitable kinds of carpet. In Ganja, that has rich traditions, were prepared carpets with various characteristics. For this reason one of Azerbaijani 
carpet groups are Ganja carpets or (Ganja-Kazakh carpets). Pay attention that in Ganja namely local kinds of carpets-palaz (carpets without of pile) are weaved [1]. These carpets that are producing by local inhabitants are differing with specific handicraft features:

1. Ganja carpets are differing with pile.

2. Thickness indicators of such kind of carpets with comparaturly small number attract attention (25 x30).

3. Composition is more distinct and simple.

4. Most of ornamental patterns have geometrical features.

5. In coloring carpet samples were used bright colors.

6. Local carpet masters skillfully used buta's amatively patterns [2].

The size of Ganja's carpets begins from 3 square meters to 10 square meters. There are 2 important carpets groups exist:

1. Ornamental carpets.

2. Carpets with a plot.

In middle ages in spheres of gentle and applied art, Ganja of inhabitants of territory, in agriculture life bone was widely applied. Bone products, raw materials that found during investigations in and around Ganja prove, that time bone processing separated from other spheres of craftsmanship. Osteology analysis prove, that most of samples are prepared from the bone of bull, caw, deer among big horde animals and sheep, goat, boar among little horde animals. Only deeding investigations in Mingechaurs there were found a lot of samples of combs, agriculture instruments, art and other bane things. Such kind of bone samples also were found in monument complexes territory of Injachay and Kerpicli in Goranboy region during excavation. Art samples and dice for playing nard, found in territory Shatal, also attracts our attention. These samples of art make more ancient history of city culture of Azerbaijan and in whole play nard. There were found knife handles, rare geometrical decorations, samples of pipe and other instruments here. During excavations there was found bone products that used as raw materials and cutting with pipe. In XI-XIII centuries this sphere of art was developing mostly. This thought is proved with a lot of bone and horn, found in zone of excavation. This period from bone there were prepared buttons, knifes and etc. Ganja and its surrounded territory are also rich with different stones. Presentation of white and in mountain and Aran Karabakh and also lime, traverse and marble building stones in and around Ganja, pure white, a lot of colored agates, chalcedony, veil, ametist, obsidian, agates, crystal and other kind of rare colored stones in the river basins of Shahdaq, Kecheldaq, and other territories created favorable ground for developing in this ancient country from ancient times stone cutting, stone grind, stone polishing and for building great modern, columned, arched, circled and four-cornered buildings here. Similar with it, but founding stone potter with simple surface in grave kurgan № 12 also proves it. Founding such kind of things on Uzerlik tepe also proves our thoughts.

\section{Materials and methods}

Majority of local wool products, richness of natural colors and existence professional carpetmaking women made for quick development carpet making craftsmanship in Ganja and in its surround territories [3].

In whole at the beginning of XIX- XX centuries the quality of carpet craftsmen were more than thousand. At the result of it during a lot of years were prepared such kind of qualities carpets as "Kohne Ganja"("Old Ganja"), "Phahrali", "Chiraqli", "Chayli”, "Samukh”, "Zeyva”, "Sarisi”,"Shadilli”.

In this period in Ganja were produced as carpet with pile, also carpets without pile.

Such kind of carpets without pile as phalas, kilim, holdall, bead, verni, sumach, heybe, carpet bag were different with qualities and colored ornamental elements.

Especially we must say that Ganja carpets have always been valued for its quality and art characteristics. As the result of in IX - XX centuries most of Ganja carpets were showed in world in fluent exhibition. In 1850, 1852 and 1912 years in Tbilisi, in 1896 - in Nizhny Novgorod, in 1900 year in Paris , in 1911 year in Turn Ganja carpets were showed and highly in international exhibition. Nowadays, Ganja's carpets are kept in authoritative museums of world, and also in collection of different people. The studying of Ganja's carpets for art characteristics quality form science point of view is very important for investigation heritage of world culture [4].

Found during archeological excavations and used in wooden treatment and knife, showed that at the beginning of XI - XIII in and around Ganja this sphere of craftsmanship in exist. Bone boards with circular surface molding decoration decoration were found in Mingechaur, in Khogali barrow № 2, Sarichoban, Borsunlu and others. Monument, that including to Borsunlu Complex is finishing with small wheel desk from bone and two omlets, prepared from teeth of boar. In this period also were prepared such kind of agriculture instruments as wood shovel, rake and etc. But they didn't reach nowadays [5].

Some of the materials consist of mace stone. They coincidence to height grave borrow № 1. Mace stone have spherical form. They are similar with materials in Middle Bronze period. Founded in ruin graves cast -ironed boiler and painted spear with thin breath and length are similar for monuments of that period of Azerbaijan (Kizilveng, Aznabyurd and etc.) In Complex Borsunlu there are grinding stones with 
hole for hanging and mace plead, prepared from grey marble in form of pear. Borsunlu mace is differing from all other monument's mace of Azerbaijan. Maces in form of pear mostly we can see in complexes in the North Iran and South Turkmenistan, that concern to the second half of second thousand $\mathrm{BC}[6]$.

Among archaeological equipment there have been found two big boards from stone "camel eyes". Base - columns, capitals, that are symbols of irreplaceable art, part of columns, different man monuments, masonry art symbols, that have Ganja, agriculture and religious meaning, especially grave monuments and phalluses, collections of different colored (red, brown, black, grey and other rare colored) stamps and symbols of decorations, that were found in Azerbaijan during archeological investigations prove it. These rare discovers in and around Ganja are known from the archaeological investigations in ancient cultural, art and trade centers of Azerbaijan, such as Mingachevir, Barda, Baku, Smamakha, Qabala, Ganja, Shatal, Beylagan, Shabran, Khazakh, Qakh, Quba, Qushchu, Shargah, Torpaggala and other archaeological and architecture complexes. The best samples of monuments, that concern to stone treatment are consists of column props, mill and gridding stones. In whole there were founded in and around Ganja a lot of samples, that concern to $\mathrm{X}$ century. They are consisting of stone figure, mills and column props. But stone equipment, found in Ganja, Shamkir and Shatal prepared from mill and candlestick. Mill is usually prepared from volcanic, quartz, limestone and basalt. They used for grinding seed, millet, slot and for other aims [7].

We meet mostly mill stones, scales and pumice stone in stone treatment. At the same time there were use $3 \mathrm{~d}$ hewed stones for decorating buildings. In this period there were prepared decorations from precious stone.

Different colored stone samples and agreements, that found in monuments of Shamakhi, Barda, Mingechaur, Qakh, Ismayilli, Quba and other regions are the best symbols of art, painting, religion, heroism and art themes of Azerbaijan. Such kind of fleece monuments have been found in village Gurzalilar of Goranboy region, in Goygol, Dashkesan and Samuch and investigated here. It is interesting, that from the workshop of these monuments have been found instruments of masters and samples of raw-materials. All these aspects show, that inhabitant of Middle Ages in and around Ganja from the ancient period did masonry, gridding and stone treatment. This sphere of art in developed middle Ages could be in high level. And rare magnificent architectural monuments in and around Ganja that stay till nowadays, prove it.

\section{Typical features of basic art handicraft kinds}

Traditional textile of art of silk weaving products has a special place in Ganja. In the city formed two main method of silk treatment:

1. Spinning

2. Winding

From the point of view silkworm breeding development and its preparing technology there were two main forms of production: so-called raw silk weaving and felt weaving. In this important technological processes it has such kind of production stages as cocoon opening, silk initial processing, preparing of raw silk, weaving technology, painting and decoration.

In the ancient Ganja during the stage of the Middle Ages the great progress of silkworm was represented by raw silk weaving. For this reason, on the basis of local traditions production of delicate silk textiles from raw silk. There were made such kind of important samples of art as atlas and kelaqai (silk kerchief). We must pay attention to the moment, that differ from the other silk fabrics, kelaqai was prepared by specialists. But distinctly of production of raw silk, that was city silkworm breeding and was man activity, felt production was woman work.

In Ganja, that know as the ancient cultural center, the saddle-making handicraft differed from others with rich old traditions. First time preparation of the vehicles was house profession. But afterwards saddle preparation needed of qualified skilled masters, so a new type of art saddle-making, started to form.

Historically the traditional art of saddle-making in Ganja developed in direction of cargo and passenger saddle making. The art of saddle-making within the local saddle-types and their components were determined on a specialization. The production of cargo or pack -saddle a rule was engaged by packsaddle maker. For this reason, in most cases, the profession was called trade of pack-saddle maker [8].

Afterwards military, economic and transportation significance of hourse was decrease, the demand for goods of saddle-making also was decrease. The reason of primitive saddle-making decreasing was wide sale of cheaper factory products.

There is no any source about glass production in and around Ganja. The majority of archaeologists agreed with the idea, that the homeland of glass production is ancient Egypt, but the famous English archaeologist, Egyptologist Petri Flinders thought, that it could be Mesopotamia or the Caucasus. Taking into account that cobalt, used in glass coloring wasn't in Egypt, the scientists thought that, it could be in the Caucasus, also in Dashkesan.

Samples of glass decorations, of BC, we met in the patterns of Ganjachay, Mingechevir, Xachbulaq and others. In these areas, the first centuries BC were found in samples of the glass plate. The majority of containers and the analysis based on graphical 
elements of the Roman scholars came to the opinion that the samples of the same scale as the Roman Empire through trade.

There are more than 2000 beads in complex materials. Colored beads have prepared of different types products. Mostly distinguish beads that prepared from blue green and grey paste. A group of beads made of bone and antimony.

A part of the hanging beads were prepared from cockleshells "Nassagibbosula" and "Suraeva Moneta". According to expert's thoughts, such kind of cockleshell that widely spared in the Indian and Pacific Ocean, also the Eastern Mediterranean region were put to Azerbaijan with economic relations.

Among the materials of Borsunlu Complex are differ with number of beats in majority and form.

In III-V centuries, the local craftsmen themselves also became to produce better-designed containers. Among the local clay and glass utensils that found in and around Ganja there were big similarity in the form and also in the decoration.

All the glass dishes found in and around Ganja are similar with the local clays on decoration of that period. Glass dishes were containing of Iron, cobalt, magnesium and other elements, that were specific elements for Ganja and its surroundings. The development history of this sphere of craftsmanship can be determined only through archaeological research. In general, information about the development of this sphere of was found in 19591960 years, glass products in and around Ganja was obtained only at the end of the twentieth century.

Results of archaeological excavations in the territory of Azerbaijan and research show that in the preparation of glass utensils were two technical methods: casting method and the method of blowing. The first of these methods is more ancient, but in the Early Middle Ages and Middle Ages were used both of them.

Produced glass alloys were transparent colored. By the addition of dusts of various metals in glass alloys people got colored glasses. We can see also to get her with different tinted green glasses also parts of blue, black and pink colored glass dish in sections of IX-X century in Shatal and Ganja. In IX-X centuries appeared dishes, that had handle and spout .

Glass products, obtained in Ganja and Shatal in the IX-X centuries, find their similarities in dwelling places of the Middle Ages in Barda, Beylagan, Mingechevir, also in the obtained materials of the neighboring republics of the same period.

Among decorations of that period yellow, white and red beads of round and plain form are met mostly. At the beginning of X-XIII centuries development of production of glass in and around Ganja characterized by improvement from the technology point of view.

Archaeological researchs show, that outside of the cities in the VIII-IX centuries, also big settlements were established. This is often due to density in cities.

Innovative basis of research of architecture and craftsmanship traditions

In the territory of Azerbaijan the oldest samples of wood treatment were found in the territory of ancient Ganja. Around Ganja area - in the region of Lake Goy-gol in the IV-III millennium BC have been discovered wooden thicker board, also wooden sugar bowl, that concern to the end of the II millennium BC, found in Mingechevir pitcher grave are material evidences of science thoughts.

Along with the works and notes of medieval authors and travelers, a lot of material samples, found in the territory of ancient Ganja, also found in Mingachevir and concern to Middle Ages trough, ladle, wooden threshing board, shows that in Ganja wood treatment and sculptor art have a rich tradition.

Wood treatment products historically have been represented in various fields of social and cultural life in Ganja:

1. Kitchen appliances: trough, quadruped, rolling-pin, mortar and pestle, ladle, spoon, trough.

2. Transport means: sleigh, car, and ski.

3. Weaving tools: comb, face.

4. Household tools: harrow, wooden plow, threshing board, spade, wooden shouvel, pitchfork, rake.

5. Musical instruments: saz, ud, tar, chamahcha, tambourine, drum.

Along with the mosque Cuma (Shah Abbash),that constructed in 1606, local samples of trade ornamentals, that built in Sheikh Javad Khan Street, that have 3 century history and was built in the nineteenth century in building of Sheikh Nizami Ganjavi's (1141-1209) representatives Sheikhzamanlys property and, that was restored in 2011, are attractive especial attention [4-11].

The formation of pottery on the territory of ancient Ganja is concern to the stages of ancient history. Basis on research works carried out by the various persons in XIX century and expertsarcheologists at the beginning of XX century in old ruins of the city and surrounding areas there were found different samples of pottery.

First of all, there have been discovered, that initial ceramic production in Ganja and its surrounding regions are belong to the VIII-VII millennium BC. From the history point of view, these ancient clay vessels, belonging to the Neolithic stage, are differing from the pottery samples of the neighboring ethnic in number characteristics. These differences are seen in preparing technology, also in the area of external surface decoration.

From the construction point of view, samples of pottery, that concern to Antique period, also to the period of Hellenism in Ganja, differed in various forms: 
1. Pictorial vases

2. Ceramic figures

3. Connected dishes

Pottery dishes, that concern to the first stages of Middle Ages of Ganja, are differing from the ceramic samples of Antique period in two features:

1) On shape.

2) For preparing techniques.

Potter's products of the Early Middle Ages of Ganja and its regions for their technical characteristic are divided into 2 major groups:

I. Glazed ceramic products.

II. Unglazed ceramic products

The main types of samples of ancient clay toys in Ganja regions are the follows:

1. Rattle.

2. Zoomorphic figures.

3. Toy dishes.

The end of middle Ages and New Period. In this historical period in Ganja and its regions ceramic has following kinds:

1. Building ceramic materials.

2. Unglazed ceramic products.

3. Glazed ceramic products.

For Middle Ages and New period among pottery products of Ganja ceramic samples as clay construction materials have great importance. First of all, glazed bricks that used in construction of most buildings in the XVII-XVIII centuries, and also in great monuments and the main construction materialair-dried bricks, attracted attention. During this period, using of baked brick has been widened and their standard sizes were as follows:

$25 \times 24 \times 5 \mathrm{~cm}$;

$25 \times 25 \times 5 \mathrm{~cm}$.

In addition to the found samples in residential areas as a result of archaeological excavations, also were found a lot of brick spoilages. According to such kind mass finding of brick spoilages, we can make the conclusion, that the bricks used in construction of buildings in Ganja, were wares of local production [8-12].

Metal treatment: (coppersmith, blacksmith, arm craft, goldsmith, currier, hating, felting, cobbling)

History and art of Azerbaijan people as rich and colorful as its nature. On decorations of this descriptive art are reflected spiritual world, living style, customs and traditions of our nation. These pearls of art on material preparing and processing techniques are divided into different kinds. Among these types of craft metal treatment is mostly developed and has ancient history. Abundance of local raw materials created favorable conditions for development of metal treatment from ancient times. In general, in the third millennium BC there was high culture of the Bronze Age in our country, and in the first millennium transition period from Bronze Age to Iron Age began. In that period in Azerbaijan there were appeared several branches of metallurgy treatment. Jewelries, daggers, arms, copper products and other samples of art have been treated so refined, that in nowadays they are protected as very valuable exhibits in famous museums in such cities, as Paris, London, Brussels, Istanbul, Tehran and other cities.

Works of art, made from metal, for their content and their form are divided into two major groups:

1) Products of art;

2) Household goods.

Household equipment, works of art, agriculture instruments, that made by Ganja crafts, have been executed into two main technical methods:

1) Casting

2) Forging

Made of precious metals gold and silver jewelries, that prepared by Ganja masters, are divided into 4 groups for wearing and putting:

1) Neck jewelries - it is included such kind of jewelries, that gold piece coin, imperial, "cardamom or barley," iyirmibeshlik" (25), medallions, "bogazaltı" (woman jewelries in ribbon form), bracelets, different kinds of beads and etc.

2) Jewelries for arms and fingers - this group include bracelets, bangles and rings with various precious stones as (turquoise, rubies, pearls and etc.).

3) Head jewelries - skull-cap and others.

4) Jewelries for clothiers [11-14].

In the first half of the XVIII-XIX centuries, as well as in other parts of Azerbaijan, in Ganja household objects, forging weapons and jewelries that made from metal were decorated with 6 technical ways.

1. Tattooing.

2.’Basma" (Pushing)

3."Karasavad"

4. Ornaments.

5. Khatemkarliq.

6. Mitering.

Weaving and dying: As in many places, production of wool, cotton and silk in and around Ganja made necessary emergence and development of weaving .Becoming weaving one of the ancient spheres of crafts in and around Ganja was connected with the rich raw material base here. Presence of useful plant species for textile, including cotton, high level development of wool area of agriculturesheep and goat breeding, camel breeding, horse breeding, presence of cotton cropping in Middle Ages and finally, regular expansion of silkworm breeding in this area created a foundation for growth of weaving here. In addition, during the research work in Mingachevir, Kazakh, Shamakhi, Sargah, Pirsaat River Basin monuments there have been found whole and parts of weaving loom and different sizes of clay and bone samples that consist to weaving [17-21].

Mousey Kalankatly notes, that, along the banks of the Kura River ... there are a large amount of silk 
(mulberry tree) and cotton. Arab author who lived in the $\mathrm{X}$ century Al-Istakhri gives big information about, that in Barda in ownerless gardens were cultivated mulberry leaves and silkworm, then mulberry silk sent to Farsistan and Khusistan for sale. His contemporary and fellow townsman Ibn Hovqal gives information about preparation of silk clothing from them. Also, Al-Istakhri provides detailed information about cutting of textile in Derbend.

The art of Textile materials, that concern to weaving craft, consists of spindle heads and needles. The remnants of dying from the Shamkir, Ganja, Shatal and Khunan prove development of dying here. Plant remains have been widely used in dying.

In traditional production of cloth manufactory trade historically played an important place. This kind of craft that developed on the basis of local raw materials was tied with cotton-growing economy. Since the time of the early Middle Ages, Ganja as
Tabriz, Ordubad have been the main center of Azerbaijan in production of cotton cloth.

In this ancient city printed cotton and calico fabrics have been widely produced. In traditional cloth productions the main place took the urban mines. In the early 30s of the XIX century in Ganja there were more than 164 people - weaving. The majority of these artists were weaving. In Ganja, which was the most important center of cloth production were produced different kinds of cotton cloth. Only in the 30s of the XIX century in Ganja were presently working 30 cloth bench. During one year this machine were producing 2000 of white cloth, 200 top of red cloth (shale) and nearly 400 thin cloths spoke [15]. In general, in Ganja from textile there were made cotton cloth with simple painting, various kinds' decorations. In most cases, in the XIX-XX centuries after coarse calico colored in white colors of, it colored to different colors.

\section{References:}

1. Akunova LF, Pribluda SZ (1979) Materialovedenie i tekhnologiya proizvodstva khudozhestvennykh keramicheskikh izdeliy: ucheb. posobie. M.: Vysshaya shkola, $216 \mathrm{p}$.

2. Guliyeva NM, Hasanov EL (2012) About ethnographic-archaeological research of some handicraft branches of Ganja during XIX - XX centuries / Progressive scientific explorations 2012: Proceedings of the 8th International scientific-practical conference. Prague: Publishing House - Education and Science s.r.o., pp.73-75.

3. The dawn of Art. (1974) Leningrad: Aurora Art Publishers, $196 \mathrm{p}$.

4. Həsənov EL (2013) Məhsəti Gəncəvi dövründə sənətkarlıq / Craftsmanship during the period of Mahsati Ganjavi / E.L. Həsənov. 1-ci nəşr. Gəncə: Elm, 175 p.

5. Häsänov EL (2012) Die Gändschänischen teppiche von XIX - XX Jahrhundert als geschichtliche - ethnographische quelle // European Science and Technology (Die Europäische Wissenschaft und die Technologien): 2nd International scientific conference. Bildungszentrum Rdk e. V. Wiesbaden, pp. 26-27.

6. Azərbaycan arxeologiyası: (2008) 6 cilddə, VI cild, Bakı: Şərq-Qərb, 632 p.

7. Kulieva NM, Gasanov EL (2011) O razvitii khudozhestvennoy keramiki $\mathrm{v}$ drevney
Gyandzhe / Materialy mezhdunarodnoy zaochnoy nauchno-prakticheskoy konferentsii Voprosy obshchestvennykh nauk: sotsiologiya, politologiya, filosofiya, istoriya. Novosibirsk: Apriori, pp. 132-135.

8. Hasanov EL (2012) Innovational ethnographic facts on investigation and teaching of some basic decorative - applied arts of Ganja of the XIX - XX centuries / Applied and Fundamental Studies: Proceedings of the 1st International Academic Conference. Saint Louis: Publishing House - Science and Innovation Center, Missouri (the United States of America). pp. 400-403.

9. Alieva AS Vorsovye kovry Azerbaydzhana XIX - nach. XX vekov. Baku: Elm, 1973. - pp. 21-25.

10. Azərbaycan etnoqrafiyası: (2007) 3 cilddə, I cild, Bak1: Şərq-Qərb, 544 p.

11. Bünyadova ST (1992) Nizami və etnoqrafiya. Bakı: Elm.

12. Burton-Brown T (1951) Excavations in Azerbaijan, 1948. London.

13. Ohmədov FM (2007) Gəncənin tarix yaddaşı. Gəncə: Elm.

14. Ofəndiyev RS (1966) Azərbaycanın bədii sənətkarlığı. Bakı: Azərnəşr.

15. Guliyeva NM, Häsänov EL (2014) Die traditionelle Gändschänischen Teppiche von Zeitraum der Aserbaidschanischen Gelehrten 
und Dichter Mirsä Schäfi Waseh als ethnoanthropologische quelle (XIX Jahrhundert). European Applied Sciences, 2: 35.

16. Hasanov EL (2014) Approccio innovativo per lo studio scientifico delle tradizioni artigianali grandi Ganja seconda metà del XIX-inizi XX secolo. Italian Science Review, 4: 642-645.

17. Hasanov EL (2014) To the question on the research of typical features of craftsmanship heritage of Ganja of the late XIX - early XX centuries. ISJ Theoretical \& Applied Science 12(20): 27-30. Soi: http://s-oi.org/1.1/TAS*12(20)7 doi: http://dx.doi.org/10.15863/TAS.2014.12.20.7

18. Hasanov EL (2014) Basic craftsmanship branches of Ganja of the second half of XIX beginning of $\mathrm{XX}$ centuries as a historicethnographical source. 社会科学と人文科学のアジアジャーナル. 大山、日本, vol. 3, Number 3, pp. 9-14.

19. Hasanov EL (2015a) Multidisciplinary approach to investigation of the basic handicraft branches of Ganja till the XX century. ISJ Theoretical \& Applied Science 1(21): 7-15. Soi: http://s-o-i.org/1.1/TAS*01(21)2 DOI: http://dx.doi.org/10.15863/TAS.2015.01.21.2

20. Həmidova İ (2000) Azərbaycan parça sənətinin tarixi inkişaf yolları. Elmi axtarışlar, VIII toplu, Bakı.

21. Həvilov HA (1991) Azərbaycan etnoqrafiyas1. Bak1: Elm.

22. Nishiaki Y, Hasanov EL (2014) About ethnoarchaeological and anthropological research of some prehistoric monuments of Ganja. ISJ Theoretical \& Applied Science, 1: 45-48. Soi: http://s-o-i.org/1.1/TAS*01(9)8 doi: http://dx.doi.org/10.15863/TAS.2014.01.9.8

23. Smith WB, Hasanov EL (2013) Importance of handicraft traditions in investigation of history of urban culture in Ganja. ISJ Theoretical \& Applied Science 11(7): 61-66. Soi: http://s-oi.org/1.1/TAS*11(7)10 doi: http://dx.doi.org/10.15863/TAS.2013.11.7.10 